\title{
Who is in charge when I have a headache? Brazilian version of the Headache-Specific Locus of Control Scale
}

\author{
Quem está no comando quando tenho uma cefaleia? Versão brasileira de Escala de Lócus \\ de Controle Específica para Cefaleia
}

\author{
Rebeca Veras de Andrade VIEIRA ${ }^{1,2}$, Fernando KOWACS ${ }^{3,4}$, Renata Gomes LONDERO ${ }^{3,5}$, \\ Liselotte Menke BAREA ${ }^{4,6}$, Vanise GRASSI' ${ }^{6}$, Luiz Eduardo Barcellos RODRIGUES², \\ Eduardo Pacheco SANTOS², William Barbosa GOMES², Gustavo GAUER²
}

\begin{abstract}
Background: Headache-Specific Locus of Control (LOC) refers to individuals' beliefs about their control over the onset, course and consequences of headaches. LOC beliefs have been associated with depression, coping strategies, headache-related disability and treatment outcomes. Objective: To test the cross-cultural adaptation and psychometric properties of a Brazilian version of the Headache-Specific Locus of Control Scale (HSLC). Methods: One hundred and thirty-four migraine outpatients completed the HSLC and provided measurements of psychopathological symptoms, pain catastrophizing, depression, anxiety, quality of life and headache-related disability. Results: The three-factor structure of the HSLC (LOC-P, LOC-C and LOC-I) was confirmed in the Brazilian sample. The instrument showed good internal consistency, with Cronbach's $\alpha$ of 0.77 for total HSLC and 0.70, 0.83 and 0.87, for LOC-P, LOC-C and LOC-I, respectively. LOC-C correlated with headache frequency and headache intensity. Along with headache intensity, depression and pain catastrophizing, LOC-I accounted for $45 \%$ of the variance (adjusted $R^{2}=0.45 ; F=12.97 ; p<0.01$ ) in headache-related disability. Conclusions: The Brazilian version of the HSLC is a valid and reliable measure of headache-specific LOC beliefs. It is important to consider the balance between the three LOCs for each individual, instead of interpreting them separately.
\end{abstract}

Keywords: Migraine Disorders; Validation Study; Depression; Anxiety; Catastrophization.

\section{RESUMO}

Introdução: O lócus de controle específico para a dor de cabeça (LOC) refere-se às crenças dos indivíduos acerca de seu controle sobre o início, o curso e as consequências das dores de cabeça. As crenças sobre LOC têm sido associadas à depressão, às estratégias de enfrentamento, à incapacidade relacionada às dores de cabeça e aos resultados do tratamento. Objetivo: Testar a adaptação transcultural e as propriedades psicométricas de uma versão brasileira da Escala de Lócus de Controle Específico para Dor de Cabeça (HSLC). Método: Cento e trinta e quatro pacientes ambulatoriais com enxaqueca completaram a HSLC e medidas de sintomas psicopatológicos, catastrofização da dor, depressão, ansiedade, qualidade de vida e incapacidade relacionada à dor de cabeça. Resultados: A estrutura de 3 fatores da HSLC (LOC-P, LOC-C e LOC-I) foi confirmada na amostra brasileira. O instrumento demonstrou boa consistência interna, com $\alpha$ de Cronbach de 0,77 para HSLC total e de 0,70, 0,83 e 0,87 para LOC-P, LOC-C e LOC-I, respectivamente. LOC-C correlacionou-se com a frequência e a intensidade da dor de cabeça. Acompanhado de intensidade da dor de cabeça, depressão e catastrofização da dor, o LOC-I foi responsável por $45 \%$ da variância $\left(R^{2}\right.$ ajustado $\left.=0,45 ; F=12,97 ; p<0,01\right)$ na incapacidade relacionada à dor de cabeça. Conclusões: $A$ versão brasileira da HSLC é uma medida válida e confiável de crenças de LOC específicas para dor de cabeça. É importante considerar o equilíbrio entre os três LOCs para cada indivíduo, em vez de interpretá-los separadamente.

Palavras-chave: Transtornos de Enxaqueca; Estudo de Validação; Depressão; Ansiedade; Catastrofização.

\footnotetext{
'Universidade do Vale do Rio dos Sinos, São Leopoldo RS, Brazil.

¿Universidade Federal do Rio Grande do Sul, Porto Alegre RS, Brazil.

${ }^{3}$ Hospital Moinhos de Vento, Porto Alegre RS, Brazil.

«Universidade Federal de Ciências da Saúde de Porto Alegre, Porto Alegre RS, Brazil.

${ }^{5}$ Hospital de Clínicas de Porto Alegre, Serviço de Neurologia, Porto Alegre, RS, Brazil.

${ }^{6}$ Santa Casa de Misericórdia de Porto Alegre, Porto Alegre RS, Brazil.

Rebeca Veras de Andrade VIEIRA (DD https://orcid.org/0000-0003-2907-8699; Fernando KOWACS (ID https://orcid.org/0000-0002-0407-407X; Renata Gomes LONDERO (ID https://orcid.org/0000-0002-9780-4739; Liselotte Menke BAREA (iD https://orcid.org/0000-0002-9531-9115; Vanise GRASSI (ID https://orcid.org/0000-0002-9859-9167; Luiz Eduardo Barcellos RODRIGUES (iD https://orcid.org/0000-0002-1587-0071; Eduardo Pacheco SANTOS (ID https://orcid.org/0000-0003-4076-5107; William Barbosa GOMES (iD https://orcid.org/0000-0001-9069-2685; Gustavo GAUER (D) https://orcid.org/0000-0002-8536-9493

Correspondence: Rebeca Veras de Andrade Vieira; E-mail: rebecavieirapsico@gmail.com

Support: Research presented in this manuscript was partially funded by the CAPES Foundation, Process n. 0598/13-5.

Conflict of interest: There is no conflict of interest to declare.

Authors' contributions: RVAV, WBG and GG: conception and design; RVAV, LEBR and EPS: acquisition of data; RVAV, FK, RGL, LMB, VG, WBG and GG: analysis and interpretation of data; RVAV: drafting the manuscript; RVAV, FK, RGL, LMB, VG, LEBR, EPS, WBG and GG: revising it for intellectual content; RVAV, FK, RGL, LMB, VG, LEBR, EPS, WBG and GG: final approval of the completed manuscript.

Received on May 28, 2020; Accepted on July 22, 2020.
} 


\section{INTRODUCTION}

Locus of control (LOC) can be defined as a belief about the direction of control that individuals have about various events in their lives. Individuals whose locus is internal (LOC-I) believe that they can exert some influence on events through their own actions, characteristics and competencies. These individuals can draw a causal relationship between their behaviors and certain outcomes. In contrast, individuals whose locus of control is external (LOC-E) believe that outcomes from events depend on luck, fate or other individuals (powerful others), occurring independently of their own actions ${ }^{1}$.

Health-related locus of control beliefs have been correlated with indicators of physical and mental health ${ }^{2,3,4}$, treatment adherence ${ }^{5}$, health-related behavior ${ }^{6}$, return to work ${ }^{7}$ and quality of life ${ }^{8}$. Several authors have pointed out that pain beliefs and coping strategies influence chronic pain and that those factors should be included among treatment targets 9 Along with self-efficacy, locus of control is one of the cognitive factors that ought to be evaluated in all patients with chronic headache ${ }^{10}$. Furthermore, chance locus of control (LOC-C) is among the psychological factors associated with chronic migraine that are susceptible to modification ${ }^{11}$. While higher LOC-I (internal) is linked to higher overall migraine-related quality of life, higher LOC-P and LOC-C (medical professionals and chance) are associated with impairments in migrainerelated quality of life ${ }^{12}$.

Locus of control also moderates the relationship between headache pain and depression. In a study conducted by Heath, Saliba, Mahmassabi, Major and Khoury ${ }^{13}$, 71 headache patients were evaluated to examine in detail the relationship between the severity of self-reported headache pain, depression and coping styles. The results showed that higher levels of LOC-I were associated with lower levels of depression. Also, LOC-I played a protective role in the model tested, thus reducing the strength of the relationship between pain severity and depression.

Evaluation of LOC beliefs in the context of headache was put into operation through construction of the HeadacheSpecific Locus of Control Scale (HSLC). In the study on the construction and validation of the HSLC ${ }^{14}$, LOC-C was positively associated with higher levels of depression, physical complaints, catastrophizing as a strategy for coping with pain and increased disability. Moreover, LOC-P was positively associated with higher levels of drug use and preference for medical treatment and LOC-I was positively associated with a preference for self-regulation treatments, such as biofeedback and relaxation training. All of these correlations remained significant even after statistically controlling for intensity and frequency of headaches. These results support the hypothesis that adaptation to headache-related problems is influenced not only by the frequency and severity of headache episodes but also by headache-specific locus of control beliefs.
Although the literature in this field indicates that it is relevant to investigate locus of control among headache patients, there is a lack of instruments in Brazil to evaluate this construct. The goal of this study was to test the cross-cultural adaptation and psychometric properties of a Brazilian version of the HSLC on a sample of patients at three tertiarylevel headache centers in Brazil.

\section{METHODS}

\section{Sample and procedure}

The sample was composed of 134 migraine patients whose diagnosis was made by experienced neurologists in accordance with the International Classification of Headache Disorders $3^{\text {rd }}$ Edition - Beta version ${ }^{15}$. The exclusion criterion was the presence of medical conditions stated in the patients' medical records that could lead to difficulties in understanding or filling out the instruments, such as a previous diagnosis of a psychotic disorder or cognitive impairment. The participants' ages ranged from 18 to 65 years $(\mathrm{M}=43.70 ; \mathrm{SD}=12.74)$. Participants were selected from outpatients registered at two public hospitals and one private hospital in southern Brazil. All of these headache centers are located in the city of Porto Alegre, Rio Grande do Sul, Brazil.

The participants were found through the patient lists at the three hospitals' headache clinics. The inclusion period ran from April 2016 to March 2017. The instruments were applied in a single session, on the same day as the patients' routine doctor's appointment. All the participants gave their informed consent prior to their inclusion in the study. The study received approval from each hospital's institutional review board. Table 1 shows the sociodemographic and clinical information of the sample. The HSLC was translated forward and backward using standard guidelines for cross-cultural adaptation ${ }^{16,17}$.

\section{Measures}

A semi-structured interview was conducted to characterize the sample and to evaluate clinical headache parameters, such as duration of disorder in years (DD), patient's time under treatment (DT), headache frequency during the last three months (HF), headache intensity during the last three months (HI) and screening for a diagnosis of medication overuse headache.

\section{Headache-Specific Locus of Control Scale}

This instrument was developed by Martin, Kenneth and Penzien ${ }^{14}$ and aims to evaluate individuals perception that their headache is determined mainly by internal factors, such as their own behavior, or external factors, such as healthcare professionals or chance (for example, hormone fluctuation or genetically inherited vulnerability). HSLC items were generated by professionals with experience in headache 
Table 1. Sociodemographic and clinical data on the sample $(n=134)$.

\begin{tabular}{|c|c|}
\hline Factor & Distribution \\
\hline Gender, n (\%) & Female 119 (88.8\%); male 15 (11.2\%) \\
\hline Age, years (SD) & $44.5(12.8)$ \\
\hline Education, $f(\%)$ & 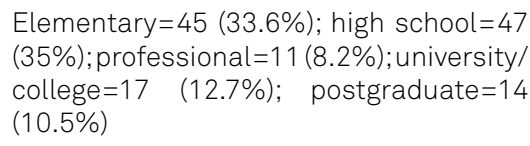 \\
\hline $\begin{array}{l}\text { Income (in current } \\
\text { minimum monthly } \\
\text { wages), n (\%) }\end{array}$ & $\begin{array}{l}\text { Up to } 1 \text { minimum wage }=12(9 \%) \text {; from } 1 \\
\text { to } 3=61(45.5 \%) \text {; from } 3 \text { to } 5=42(31.3 \%) \text {; } \\
\text { from } 5 \text { to } 10=13(9.7 \%) \text {; more than } 10=6 \\
(4.5 \%)\end{array}$ \\
\hline Labor status, n (\%) & $\begin{array}{l}\text { Employed }=67 \quad(50 \%) ; \quad \text { unemployed }=67 \\
(50 \%)\end{array}$ \\
\hline Marital status, n (\%) & $\begin{array}{l}\text { Single }=34 \quad(25.4 \%) ; \quad \text { married }=55 \\
(41 \%) ; \text { living with partner }=24(17.9 \%) \text {; } \\
\text { divorced=16 }(11.9 \%) ; \text { widowed }=5(3.7 \%)\end{array}$ \\
\hline Diagnosis, n (\%) & $\begin{array}{l}\text { Episodic migraine }=102(76.1 \%) \text {; chronic } \\
\text { migraine }=18(13.4 \%) ; \text { medication overuse } \\
\text { headache }=14(10.4 \%)\end{array}$ \\
\hline $\begin{array}{l}\text { DD (years)/DT } \\
\text { (years) }\end{array}$ & $21.78(14.67) / 10.07(10.72)$ \\
\hline $\mathrm{HF} / \mathrm{HI}$ & $27.59(24.43) / 8.17(2.01)$ \\
\hline
\end{tabular}

Mean (standard deviation); DD: duration of disease (in years); DT: duration of treatment (in years); HF: headache frequency over the last three months in days; $\mathrm{HI}$ : headache intensity attributed by the participants regarding their pain over the last three months on a scale ranging from $0-10$.

treatment and items from the Multidimensional Health Locus of Control scale (MHLC). After statistical procedures, the scale resulted in 33 items. The HSLC is composed of three subscales (internal, chance and healthcare professionals) with 11 items each, evaluated on a Likert scale ranging from 1 (strongly disagree) to 5 (strongly agree). The instrument shows good reliability, with Cronbach's alpha of 0.84 , 0.86 , and 0.88 for each subscale, respectively.

\section{Self-Reporting Questionnaire}

This is a questionnaire for screening of psychiatric disorders at the primary care level developed by Harding et al..$^{18}$ and validated in Brazil by Mari and Willians ${ }^{19}$. It is composed of 24 questions divided into two sections: 20 questions are aimed at detection of "neurotic" disorders and the remaining four questions assess "psychotic" disorders. The "neurotic" disorders comprise mood, anxiety and somatoform disorders, assessed through the SCID-IV-TR (Structured Clinical Interview for DSM-IV-TR $)^{20}$. In the present study, only the first section (neurotic disorders) was used. By scoring 7 or more points on this subscale, individuals fulfill the criterion for a possible neurotic disturbance.

\section{Short form Health Questionnaire}

The instrument is an indicator of overall health status and has eight scaled scores: vitality (VT), physical functioning
(PF), bodily pain (BP), general health perceptions (GH), physical role functioning (PR), emotional role functioning (ER), social role functioning (SF) and mental health $(\mathrm{MH})^{21,22}$. The Brazilian version of the SF-36 is considered to be a reliable and valid measure of quality of life ${ }^{23}$.

\section{Headache Impact Test}

This is a six-item questionnaire developed by Kosinski et al. ${ }^{24}$ that is used to measure the impact of headaches on daily activities, including work, school, social activities, pain intensity, fatigue and bedtime, frustration and concentration difficulties. Each item is answered on a five-point Likert scale $(6=$ never, $8=$ rarely, $10=$ sometimes, $11=$ very often and 13=always). The higher the score obtained is, the greater the degree of impact also is. Martin et al..$^{25}$ examined the psychometric properties of the HIT-6 in 11 languages and 14 countries and showed that the Portuguese version has good reliability, comparable with the original version. The instrument has good internal consistency, with Cronbach's alpha of 0.79 .

\section{Pain Catastrophizing Scale}

This instrument was originally developed by Sullivan et al..$^{26}$ to assess catastrophizing as a style of negative cognition relating to pain. Catastrophizing refers to a single construct that is evaluated in three dimensions: magnification, rumination and helplessness. In Brazil, the scale was adapted and validated by Sehn et al. ${ }^{27}$ and shows a good level of internal consistency, with Cronbach's alpha ranging from 0.86 to 0.93 among the magnification, rumination and helplessness subscales.

\section{Patient Health Questionnaire and Generalized Anxiety Disorder 7}

The PHQ-9 and GAD-7 are instruments for evaluating depression and anxiety in accordance with the criteria of the Diagnostic and Statistical Manual of Mental Disorders (DSM-IV), respectively. The PHQ-9 is composed of nine items, evaluated on a four-point Likert scale $(0=$ not at all, $1=$ several days, $2=$ more than half the days and $3=$ nearly every day). The total score can range from 0 to 27 , and values greater than or equal to 10 are considered to be a positive indicator of major depression. The PHQ-9 is considered to be a reliable and valid measure of depression severity ${ }^{28}$. In Brazil, this instrument was validated by Osório et al..$^{29}$ in the context of primary healthcare. The GAD-7 was developed by Spitzeret al..$^{30}$ and validated by Löwe et al..$^{31}$. It is composed of seven items, evaluated on a four-point Likert scale $(0=$ not at all, $1=$ several days, $2=$ more than half the days and $3=$ nearly every day). The sum of the scores ranges from 0 to 21 . Values greater than or equal to 10 are positive indicators of anxiety disorders. In the context of headache studies, both the PHQ-9 and the GAD-7 are considered to be reliable and valid screening instruments for major 
depressive disorders and generalized anxiety disorders in patients with migraine ${ }^{32,33}$.

\section{Data analysis}

Descriptive statistical analyses were performed on the sociodemographic and clinical data. The psychometric properties of the Brazilian version of the HSLC were analyzed using confirmatory factor analysis (CFA), internal consistency and convergent validity. In the CFA, the maximum likelihood (ML) estimation method was chosen, using the R Studio software. We used the following adjustment indices with their respective reference values: root mean square error of approximation (RMSEA $\leq 0.05$ or $\leq 0.08$ with a $90 \%$ confidence interval) and statistical significance using the chi-square test $(\mathrm{p} \geq 0.05)$. Internal consistency was analyzed using the Cronbach's $\alpha$ coefficient and composite reliability ${ }^{34}$, considering the standard factorial loads of the items. Values greater than or equal to 0.7 were considered adequate. Convergent validity was investigated by correlating HSLC scores with the Self-Reporting Questionnaire (SRQ), SF-36, Headache Impact Test (HIT-6), Pain Catastrophizing Scale (PCL), PHQ-9 and GAD-7. Additionally, multiple regression analysis was conducted to examine the relative contributions of headache frequency, headache intensity, depression, anxiety and LOC beliefs to the prediction of headache-related disability. Inferential statistics were run using Statistical Package for the Social Sciences (SPSS), version 22, adopting a 5\% significance level.

\section{RESULTS}

A total of 134 patients were included. Because some patients could not fill out all instruments, the number of patients included in the computations varied from 106 to 134 for each measure. Table 1 shows the sociodemographic and clinical data for the sample. Descriptive statistics for study measures are presented in Table 2.

The three-factor structure of the HSLC (LOC-P, LOC-C and LOC-I) was confirmed through confirmatory factor analysis (CFA). The model was adjusted to the empirical data (X²/d.f. $=1.77$, RMSEA $=0.07$ and SRMR $=0.09)$, with factor loadings of between 0.35 and 0.72 for LOC-C; 0.55 and 0.69 for LOC-I and 0.40 to 0.63 for LOC-P. For LOC-P, item 27 ("When my doctor makes a mistake, I am the one to suffer from headaches"), item 12 ("Just seeing my doctor helps my headaches") and item 30 ("Health professionals keep me from getting headaches") exhibited lower factor loadings: $0.17,0.23$ and 0.32 respectively. Thus, the structure of the original version of the scale was retained in the Brazilian version.

Table 3 shows item correlations with the scale scores and Cronbach's $\alpha$ of each HSLC subscale. The Brazilian version of the HSLC showed good internal consistency, with Cronbach's $\alpha$ of 0.77 .
Table 2. Descriptive statistics on study measures.

\begin{tabular}{lcc|}
\hline Measure & Mean (SD) & Range \\
\hline LOC-I $(n=134)$ & $36.34(5.97)$ & 29 \\
LOC-P $(n=134)$ & $35.32(5.75)$ & 27 \\
LOC-C $(n=134)$ & $40.60(7.16)$ & 35 \\
PHQ-9 $(n=133)$ & $10.26(6.71)$ & 27 \\
GAD-7 $(n=134)$ & $10.15(6.15)$ & 21 \\
PCS $(n=133)$ & $42.80(12.12)$ & 46 \\
SRQ $(n=133)$ & $10.15(4.97)$ & 20 \\
HIT-6 $(n=133)$ & $62(7.99)$ & 38 \\
PF & $62.91(29.32)$ & 100 \\
PR & $39.92(42.71)$ & 100 \\
BP & $39.40(22.27)$ & 90 \\
GH & $8.17(2.01)$ & 8 \\
VT & $12.38(3.80)$ & 18 \\
SF & $57.56(28.80)$ & 100 \\
ER & $38.06(43.48)$ & 100 \\
MH & $55.01(10.88)$ & 68 \\
\hline SD Standard & & \\
\hline
\end{tabular}

SD: standard deviation; LOC-I: internal locus of control; LOC-P: healthcare professional locus of control; LOC-C: chance locus of control; PHQ-9: Patient Health Questionnaire 9; GAD-7: Generalized Anxiety Disorder; PCS: Pain Catastrophizing Scale; HIT-6: Headache Impact Test; PF: physical functioning; PR: physical role functioning; BP: bodily pain; GH: general health perceptions; VT: vitality; SF: social role functioning; ER: emotional role functioning; $M H$ mental health.

Table 3. Item correlations with scale scores and Cronbach's $\alpha$ of Headache-Specific Locus of Control items.

\begin{tabular}{lcc}
\hline HSLC subscale & $\begin{array}{c}\text { Corrected item - total } \\
\text { correlation, mean (range) }\end{array}$ & Cronbach's $\alpha$ \\
\hline Internal & $0.58(0.50-0.68)$ & 0.87 \\
$\begin{array}{l}\text { Healthcare } \\
\text { professionals }\end{array}$ & $0.35(0.16-0.52)$ & 0.70 \\
Chance & $0.50(0.35-0.64)$ & 0.83 \\
\hline
\end{tabular}

HSLC: Headache-Specific Locus of Control.

Convergent validity was evaluated by correlating HSLC scores with other study measures. Table 4 depicts the correlation matrix. Several correlations between study measures and both LOC-I and LOC-P were statistically significant, such as psychopathological symptoms, depression, anxiety, pain catastrophizing, headache-related disability and SF-36 domains. Unlike the other subscales, LOC-C correlated only with headache frequency and headache intensity. All three HSLC subscales (LOC-P, LOC-I and LOC-C) showed strong and statistically significant correlations with total HSLC.

Table 5 shows the results from a multiple regression analysis that was conducted to test the contributions of headache frequency, headache intensity, psychopathological symptoms, depression, anxiety, pain catastrophizing and LOC beliefs to prediction of headache-related disability. 
Table 4. Correlations between Headache-Specific Locus of Control Subscales and other studies.

\begin{tabular}{|c|c|c|c|}
\hline & 1 & 2 & 3 \\
\hline HSLC & $0.89 * \star$ & $0.68 * \star$ & $73^{* *}$ \\
\hline LOC-P & - & & \\
\hline LOC-I & $0.56 * \star$ & - & \\
\hline LOC-C & $0.51 * *$ & 0.08 & - \\
\hline$S R Q$ & $0.42 * \star$ & $0.41 * *$ & 0.11 \\
\hline Depression & $0.37 \star \star$ & $0.40 * *$ & 0.05 \\
\hline Anxiety & $0.34 * \star$ & $0.37 * \star$ & 0.19 \\
\hline Pain catastrophizing & $0.30 * *$ & $0.39 * *$ & 0.02 \\
\hline Headache frequency & -0.09 & -0.06 & $0.23 * *$ \\
\hline Headache intensity & 0.07 & 0.09 & $0.27 * \star$ \\
\hline HIT-6 & $0.26 * \star$ & $0.40 * \star$ & 0.01 \\
\hline \multicolumn{4}{|l|}{ SF-36 domains } \\
\hline PF & $-0.20 *$ &,$- 33 * *$ & -0.04 \\
\hline PR & $-0.37 * \star$ &,$- 38 * \star$ & -0.08 \\
\hline BP & $-0.29 * \star$ & $-0.30 * \star$ & -0.12 \\
\hline $\mathrm{GH}$ & $-0.34 \star \star$ & $-0.46 \star \star$ & 0.02 \\
\hline VT & $-0.34 * *$ & -0.12 & -0.12 \\
\hline SF & $-0.28 \star \star$ & $-0.37 * \star$ & -0.05 \\
\hline ER & $-0.29 * \star$ & $-0.26 \star \star$ & -0.07 \\
\hline $\mathrm{MH}$ & -0.10 & $-0.23 * \star$ & -0.04 \\
\hline
\end{tabular}

${ }^{*} \mathrm{p}<0.05 ; * * \mathrm{p}<0.01$; HSLC: Headache-Specific Locus of Control scale; LOC-P: healthcare professional locus of control; LOC-I: internal locus of control; LOC-C: chance locus of control; SRQ: Self-Reporting Questionnaire; HIT-6: Headache Impact Test; PF: physical functioning; PR: physical role functioning; BP: bodily pain; GH: general health perceptions; VT: vitality; SF: social role functioning; $\mathrm{ER}$ : emotional role functioning role; $\mathrm{MH}$ : mental health.

Table 5. Regression analysis for headache-related disability $(n=134)$.

\begin{tabular}{lccc|}
\hline & Beta & $\mathrm{t}$ & Sig \\
\hline HF & 0.09 & 1.34 & 0.18 \\
HI & 0.31 & 4.31 & $0.00^{\star *}$ \\
\hline SRQ & 0.13 & 1.18 & 0.24 \\
PHQ-9 & 0.28 & 2.34 & $0.02^{*}$ \\
GAD-7 & -0.10 & -0.52 & 0.60 \\
PCS & 0.20 & 2.6 & $0.01^{*}$ \\
\hline LOC-I & 0.19 & 2.18 & $0.03^{\star}$ \\
LOC-P & -0.18 & -1.86 & 0.07 \\
\hline LOC-C & 0.10 & 0.75 & 0.45 \\
\hline
\end{tabular}

${ }^{*} p<0.05 ;{ }^{*} p<0.01$. Method Enter. Durbin Watson: 2.12; HF: headache frequency; HI: headache intensity; SRQ: Self-Reporting Questionnaire; PHQ9: Patient Health Questionnaire 9; GAD- 7: Generalized Anxiety Disorder; PCS: Pain Catastrophizing Scale; LOC-P: healthcare professional locus of control; LOC-I: internal locus of control; LOC-C: chance locus of control.

Along with headache intensity, depression and pain catastrophizing, LOC-I accounted for $45 \%$ of the variance in headache-related disability $\left(\mathrm{R}_{2}\right.$ adjusted $\left.=0.45 ; \mathrm{F}=12.97 ; \mathrm{p}<0.01\right)$.

\section{DISCUSSION}

The present study aimed to test the cross-cultural adaptation and psychometric properties of a Brazilian version of the HSLC on a sample of patients from three tertiary-level headache centers. In a CFA, the Brazilian version of the HSLC maintained the three-factor structure from the original instrument and showed good internal consistency, with Cronbach's $\alpha$ of 0.77 for the full scale and $0.70,0.83$ and 0.87 for LOC-P, LOC-C and LOC-I respectively.

LOC-I and LOC-P showed statistically significant correlations with psychopathological symptoms (SRQ), depression (PHQ-9), anxiety (GAD-7), pain catastrophizing (PCS), headache-related disability (HIT-6) and seven of the eight quality of life domains (SF-36). Unlike the other subscales, LOC-C correlated only with headache frequency and headache intensity. As in the HSLC original study ${ }^{14}$, LOC-I scores were positively correlated with depression and headacherelated disability and LOC-P scores were positively correlated with pain catastrophizing and headache-related disability. The direction and degree of those correlations were in line with the results found in validation studies on other clinical populations ${ }^{35,36}$. Moreover, the lack of correlations between the three LOCs and sociodemographic variables (age, education labor status, income and marital status) demonstrates the relevance of considering correlations with other psychological variables with which LOC beliefs were associated.

The current results require a return to the conceptual issues of the construct investigated in this study. "Internal believers" might feel responsible for both successes and failures that happen to them. "External believers" might attribute their successes to other people's actions or to good fortune, or also blame other people, facts or fate for their failures. In the case of headache patients, extreme internal believers may display cognitive distortions such as personalization, blame or labeling regarding their treatment or disease. Moreover, extreme external believers might become fatalistic and display psychological distress, such as depressive and anxiety symptoms associated with helplessness. Ultimately, LOC-I means engaging more frequently in actions that decrease the risk of triggering a new episode of headache, LOC-P means relying on others and on their knowledge to learn how to better manage headaches and LOC-C means accepting the impossibility of having total control over all headache triggers. The healthiest way to deal with headaches and their impact is by balancing all three LOCs. It is important to consider the balance between the three LOCs for each individual, thereby avoiding the risk of separate interpretation of LOC factors ${ }^{37}$.

Along with headache intensity, depression and pain catastrophizing, LOC-I accounted for $45 \%$ of the variance in headache-related disability. The inclusion of the internal locus of control as a predictor of headache-related 
disability reinforces the need for interventions in those beliefs. Patients need to have a sense of agency, for important risk factors for chronic migraine to be modified. These factors include overuse of acute migraine medication, ineffective acute treatment, obesity, depression and stress life events $^{38}$. As stated previously, LOC beliefs have been considered to be a relevant psychological factor for all chronic headache patients ${ }^{10}$.

The present study had some limitations that should be mentioned. All the patients in the study were treated in tertiary-level healthcare centers and came from the southern region of Brazil. Future studies on patients in different regions in Brazil and on people who are not under routine treatment could provide further evidence of validity for the HSLC and decrease the selection bias of the sample.
The Brazilian version of the HSLC was considered to be a valid and reliable measure of headache-specific LOC beliefs. The instrument showed good internal consistency, was significantly correlated with a variety of relevant clinical measures and was considered to be a significant predictor of headache-related disability.

\section{ACKNOWLEDGEMENTS}

We thank Professor Kenneth Holroyd for providing the copy of the original version of the HSLC and for his valuable contributions to the process of adaptation of the instrument. Furthermore, our sincere gratitude to Juliana Sbicigo for the refined statistical advice.

\section{References}

1. Rotter JB. Generalized expectancies for internal versus external control of reinforcement. Psychol Monogr. 1966;80(1):1-28. https:// doi.org/10.1037/h0092976

2. Bunce D, Batterham PJ, Christensen H, Mackinnon AJ. Causal associations between depression symptoms and cognition in a community-based cohort of older adults. Am J Geriatr Psychiatry. 2014 Dec;22(12):1583-91. https://doi.org/10.1016/j.jagp.2014.01.004

3. Cohen ML, Testa SM, Pritchard JM, Zhu J, Hoop JL. Overlap between dissociation and other psychological characteristics in patients with psychogenic nonepileptic seizures. Epilepsy Behav. 2014 May;34:479. https://doi.org/10.1016/j.yebeh.2014.03.001

4. Indelicato L, Mariano V, Galasso S, Boscari F, Cipponeri E, Negri C, et al. Influence of health locus of control and fear of hypoglycemia on glycemic control and treatment satisfaction in people with Type 1 diabetes on insulin pump therapy. Diabet Med. 2017 May;34(5):691-7. https://doi.org/10.1111/dme.13321

5. Kretchy IA, Owusu-Daaku FT, Danquah S. Locus of control and anti-hypertensive medication adherence in Ghana. Pan Afr Med J. 2014;17(Suppl 1):13. https://doi.org/10.11694/pamj. supp.2014.17.1.3433

6. Gacek M. Selected personality - related determinants of alcohol beverage consumption among Polish elite team sport athletes. Rocz Panstw Zakl Hig. 2016;67(3):263-9.

7. Rinaldo $U$, Selander J. Return to work after vocational rehabilitation for sick-listed workers with long-term back, neck and shoulder problems: A follow-up study of factors involved. Work. 2016 Sep;55(1):115-31. https://doi.org/10.3233/WOR-162387

8. Milte CM, Luszcz MA, Ratcliffe J, Masters S, Crotty M. Influence of health locus of control on recovery of function in recently hospitalized frail older adults. Geriatr Gerontol Int. 2015 Mar;15(3):341-9. https://doi.org/10.1111/ggi.12281

9. Boschen KA, Robinson E, Campbell KA, Muir S, Oey E, Janes $K$, et al. Results from 10 years of a CBT pain self-management outpatient program for complex chronic conditions. Pain Res Manag. 2016;2016:4678083. https://doi.org/10.1155/2016/4678083

10. Nicholson RA. Chronic headache: the role of a psychologist. Curr Pain Headache Rep. 2010 Feb;14(1):47-54. https://doi.org/10.1007/ s11916-009-0087-9

11. Seng EK, Buse DC, Klepper JE, Mayson SJ, Grinberg AS, Grosberg $\mathrm{BM}$, et al. Psychological factors associated with chronic migraine and severe migraine-related disability: an observational study in a tertiary headache center. Headache. 2017 Apr;57(4):593-604. https:// doi.org/10.1111/head.13021

12. Grinberg AS, Seng EK. Headache-specific locus of control and migrainerelated quality of life: understanding the role of anxiety. Int J Behav Med. 2017 Feb;24(1):136-43. https://doi.org/10.1007/s12529-016-9587-2

13. Heath RL, Saliba M, Mahmassabi O, Major SC, Khoury BA. Locus of control moderates the relationship between headache pain and depression. J Headache Pain. 2008 Oct;9(5):301-8. https://doi. org/10.1007/s10194-008-0055-5

14. Martin NJ, Holroyd KA, Penzien DB. The headache specific locus of control scale: adaptation to recurrent headaches. Headache. 1990 Nov;30(11):729-34. https://doi.org/10.1111/j.1526-4610.1990. hed3011729.x

15. Headache Classification Committee of the International Headache Society (IHS) The International Classification of Headache Disorders, 3rd edition (beta version). Cephalalgia. 2013 Jul;33(9):629-808. https://doi.org/10.1177/0333102413485658

16. Beaton DE, Bombardier C, Guillemin F, Ferraz MB. Guidelines for the process of cross-cultural adaptation of self-report measures. Spine (Phila Pa 1976). 2000 Dec 15;25(24):3186-91. https://doi. org/10.1097/00007632-200012150-00014

17. Borsa JC, Damásio BF, Bandeira DR. Adaptação e validação de instrumentos psicológicos entre culturas: algumas considerações. Paidéia. 2012 Sep-Dec;22(53):423-32. https://doi.org/10.1590/ S0103-863X2012000300014

18. Harding TW, De Arango MV, Baltazar J, Climent CE, Ibrahim HHA, Ladrido-Ignacio L, et al. Mental disorders in primary health care: a study of their frequency and diagnosis in four developing countries. Psychol Med. 1980 May;10(2):231-41. https://doi.org/10.1017/ s0033291700043993

19. Mari J, Willians PA. A validity study of a psychiatric screening questionnaire (SRQ-20) in primary care in the city of São Paulo. Br J Psychiatry. 1986 Jan;148:23-6. https://doi.org/10.1192/bjp.148.1.23

20. Gonçalves DM, Stein AT, Kapzinski F. Avaliação de desempenho do Self-Reporting Questionnaire como instrumento de rastreamento psiquiátrico: um estudo comparativo com o Structured Clinical Interview for DSM-IV-TR. Cad Saúde Pública. 2008 Feb;24(2):380-90. https://doi.org/10.1590/S0102-311X2008000200017

21. Ware JE, Kosinski M. Interpreting SF-36 summary health measures: a response. Qual Life Res. 2001;10(5):405-13; discussion 415-20. https://doi.org/10.1023/a:1012588218728 
22. Ware JE Jr, Kosinski M, Bayliss MS, McHorney CA, Rogers WH, RaczekA. Comparison of methods for the scoring and statistical analysis of SF-36 health profile and summary measures: summary of results from the medical outcomes study. Med Care. 1995 Apr;33(4 Suppl):AS264-79.

23. Ciconelli RM, Ferraz MB, Santos W, Meinão I, Quaresma MR. Tradução para a língua portuguesa e validação do questionário genérico de avaliação de qualidade de vida SF-36 (Brasil SF-36). Rev Bras Reumatol. 1999 May-Jun;39(3):143-50

24. Kosinski M, Bayliss MS, Bjorner JB, Ware JE Jr, Garber WH, Batnhorst $A$, et al. A six-item short form survey for measuring headache impact: the HIT-6. Qual Life Res. 2003 Dec;12(8):963-74. https://doi. org/10.1023/a:1026119331193

25. Martin M, Blaidell B, Kwong JW, Bjorner J B. The Short-Form Headache Impact Test (HIT-6) was psychometrically equivalent in nine languages. J Clin Epidemiol. 2004 Dec;57(12):1271-8. https:// doi.org/10.1016/j.jclinepi.2004.05.004

26. Sullivan MJ, Bishop S, PivikJ. The Pain Catastrophizing scale: development and validation. Psychol Assess. 1995;7,524-32. https:// doi.org/10.1037/1040-3590.7.4.524

27. Sehn F, Chachamovich E, Vidor LP, Dall-Agnol L, De Souza IC, Torres IL, et al. Cross-cultural adaptation and validation of the Brazilian Portuguese version of the pain catastrophizing scale. Pain Med. 2012 Nov;13(11):1425-35. https://doi.org/10.1111/j.15264637.2012.01492.x

28. Kroenke K, Spitzer RL, Williams JB. The PHQ-9: validity of a brief depression severity measure. J Gen Intern Med. 2001 Sep;16(9):60613. https://doi.org/10.1046/j.1525-1497.2001.016009606.x

29. Osório FL, Mendes AV, Crippa JA, Loureiro SR. Study of the discriminative validity of the $\mathrm{PHQ}-9$ and $\mathrm{PHQ}-2$ in a sample of Brazilian women in the context of primary health care. Perspect Psychiatr Care. 2009 Jul;45(3):216-27. https://doi.org/10.1111/j.17446163.2009.00224.x
30. Spitzer RL, Kroenke K, Williams JB, Löwe B. A brief measure for assessing generalized anxiety disorder: the GAD-7. Arch Intern Med. 2006 May;166(10):1092-7. https://doi.org/10.1001/ archinte.166.10.1092

31. Löwe B, Decker O, Müller S, Brähler E, Schellberg D, Herzog $W$, et al. Validation and standardization of the Generalized Anxiety Disorder Screener (GAD-7) in the general population. Med Care. 2008 Mar;46(3):266-74. https://doi.org/10.1097/ MLR.0b013e318160d093

32. Seo JG, Park SP. Validation of the Patient Health Questionnaire-9 (PHQ-9) and PHQ-2 in patients with migraine. J Headache Pain. 2015;16:65. https://doi.org/10.1186/s10194-015-0552-2

33. Seo JG, Park SP. Validation of the Generalized Anxiety Disorder-7 (GAD-7) and GAD-2 in patients with migraine. J Headache Pain. 2015 Nov;16:97. https://doi.org/10.1186/s10194-015-0583-8

34. Hair JF. Multivariate data analysis: a global perspective. 7. ed. London: Pearson Education; 2009.

35. Hansen JS, Bendtsen L, Jensen R. Psychometric properties of the Danish versions of headache-specific locus of control scale and headache management self-efficacy scale. J Headache Pain. 2009 Oct;10(5):341-7. https://doi.org/10.1007/s10194-009-0143-1

36. Cano-García FJ, Rodríguez-Franco L, López-Jiménez AM. A shortened version of the Headache-Specific Locus of Control Scale in Spanish population. Headache. 2010 Sep;50(8):1335-45. https:// doi.org/10.1111/j.1526-4610.2009.01588.x.

37. Cano-García FJ, Rodríguez-Franco L, López-Jiménez AM. Locus of control patterns in headaches and chronic pain. Pain Res Manag. 2013 Jul-Aug;18(4):e48-e54. https://doi.org/10.1155/2013/424839

38. May A, Schulte LH. Chronic migraine: risk factors, mechanisms and treatment. Nat Rev Neurol. 2016 Aug;12(8):455-64. https://doi. org/10.1038/nrneurol.2016.93 